\title{
Crude Oil Export: A Comparative Analysis using Artificial Neural Network and ARIMA
}

\author{
Teg Alam \\ College of Business Administration, Prince Sattam Bin Abdulaziz University, Al Kharj, Kingdom of Saudi Arabia \\ E-mail: t.alam@psau.edu.sa
}

\begin{abstract}
The key purpose of this study is to examine the forecasting of total annual crude oil export of the Kingdom of Saudi Arabia. The present paper is based on Secondary data taken from annual reports of Saudi Arabian Monetary Authority (SAMA).

The ANN and ARIMA models for forecasting are the important tools and techniques in order to illustrate the superior growth in the economy of the country. In this study, "ANN" and "Autoregressive Integrated Moving Average models" (ARIMA) have been used for predicting the total annual crude oil export of the Kingdom of Saudi Arabia.

With the help of statistical software, this study tries to predict a time series data by illustrating the ANN and ARIMA models on total annual crude oil export.

The total annual crude oil export of the Kingdom is gradually increasing after the year 2003. This research shall benefit the Government Administration to study about crude oil export.

The outcomes of the study present that ANN model is better to predict the total annual crude oil export of the Kingdom.

This study provides an insight into the position of forecasting the total annual crude oil export. The Government organization can be applied this study in making the strategic plans.
\end{abstract}

Key words: ANN, ARIMA, Forecasting, Crude Oil, Kingdom of Saudi Arabia.

\section{INTRODUCTION}

The Kingdom of Saudi Arabia is one of the best economies amongst the top twenty countries of the world. The Kingdom is the largest exporter of petroleum in the world as it has the second-largest proven petroleum and the fifth-largest proven natural gas reserves. The economy of the country depends on them.

In the year 2016, the Kingdom launched its "Saudi Vision 2030 " in order to reduce the dependency of the country on oil and diversify its economic resources. The Kingdom is one of the strongest economies in the Arab world.
Saudi Arabia exported SAR 611.48B and imported SAR491.43B in the year 2016, resulting in a positive trade balance of SAR 119.29B. The GDP of Saudi Arabia was SAR 2423.40B and its GDP per capita was SAR 204.08K.

The top most exports of Saudi Arabia are Crude Petroleum (SAR 360.51 B), Refined Petroleum (SAR 48.77 B), Ethylene Polymers (SAR37.89 B), Propylene Polymers (SAR 18.49 B) and Ethers (SAR 13.51 B).

\section{RESEARCH OBJECTIVE}

The objectives of the research are given below:

- To analyze the forecasting of total annual crude oil export of the Kingdom of Saudi Arabia.

- To examine the trend of the forecasting of total annual crude oil export.

- To examine the ACF and PACF of total annual crude oil export.

- To illustrate the Residual Analytic for ANN and ARIMA $(0,2,1)$ Model.

\section{LITERATURE REVIEW}

ARIMA Models were commonly used in different areas. J, Uddin [1] researched the time series conduct of Bangladesh trade in imports and exports and discovered that Bangladesh's complete imports and exports follow random walks or are regarded to be non-stationary time series. There is also proof that the connection between export and import is long-term co-integrating.

Mohammad et al. [2] researched inflow forecasting and discovered that the capacity of ARMA and ARIMA models is compared in the Taleh Zang station forecast of Dez reservoir inflow.

Olajide et al. [3] studied on forecasting inflation rate in Nigeria using ARIMA model.

Mehmet [4] studied weather forecasting and discovered that ANFIS is more capable of capturing water temperature dynamic conduct than ARIMA.

In Time Series Models, G.M. Ljung and G. Box [5] researched a metric of absence of fit.

Tularam G. A. and Saeed T. [6] compared the overall performance accuracy of various time-series methods for oil prices and discovered that the $\operatorname{ARIMA}(2,1,2)$ version provided extra accurate forecasts than other methods. 
Biljana Petrevska [7] researched predicting the demand for tourism from A.R.I.M.A. models and clarified that the upward trend in the demand for global tourism will remain in the near future, pointing to favorable impulses and expectations of constant growth by 2018 .

Anthony et al. [8] illustrated essential factors, first off the factors affecting the fee of oil and secondly methods to predict this rate the use of distinctive methods.

Wiri, Leneenadogo and Tuaneh, Godwin Lebari [9] found that the pre- intervention models was found to be more superior to the conventional ARIMA and post intervention models, etc.

\section{METHODS AND MATERIALS}

\subsection{Artificial Neural Network(ANN)}

'ANN' attains a huge collection of units that are interrelated in some pattern to allow communication between the units. These units are stated as nodes or neurons.

Each neuron is linked with other neuron through a connection link. Each connection link is connected with a weight that has facts about the input signal. Output signals, which are created after joining the input signals.

\subsubsection{Basic Model of Artificial Neural Network}

The diagram embodies the general model of ANN is given in Figure 1.

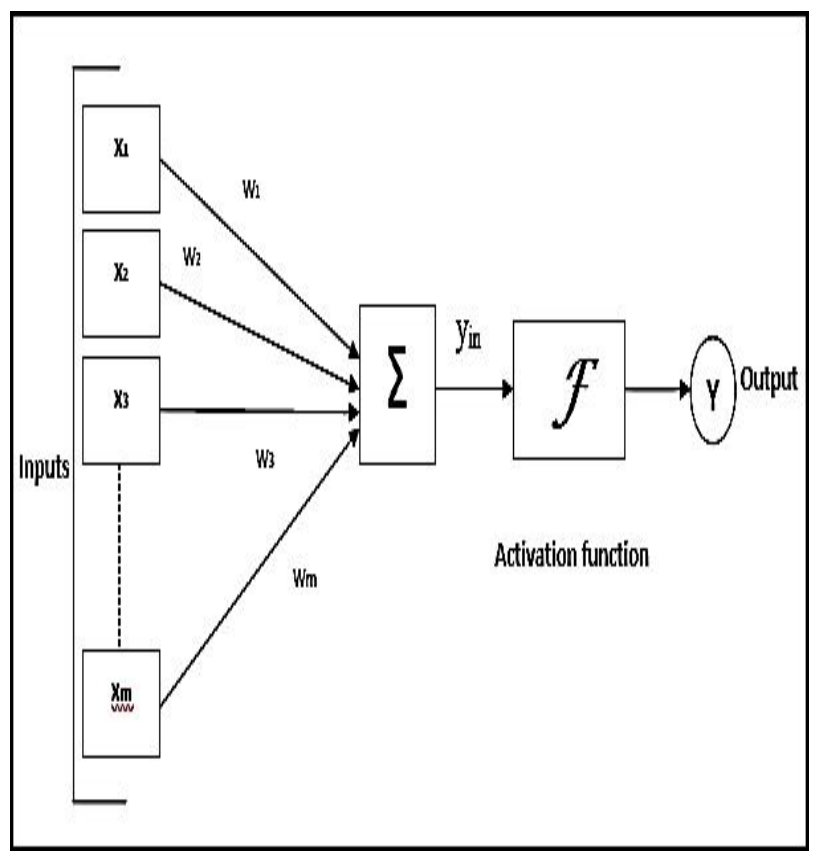

Figure 1: Neural Network

General model of ANN, the input computed as-

$$
\begin{aligned}
& \mathrm{y}_{\mathrm{in}}=\mathrm{x}_{1} \mathrm{w}_{1}+\mathrm{x}_{2} \mathrm{~W}_{2}+\mathrm{x}_{3} \mathrm{~W}_{3}+\ldots+\mathrm{x}_{\mathrm{m}} \mathrm{wm} \\
& \text { i.e., } \quad \mathrm{y}_{\mathrm{in}}=\Sigma \mathrm{x}_{\mathrm{i}} \mathrm{W}_{\mathrm{i}}
\end{aligned}
$$

The output computed as-

$$
\mathrm{Y}=\mathrm{F}(\mathrm{yin})
$$

\section{2. "AUTOREGRESSIVE-INTEGRATED- MOVING AVERAGE” (ARIMA)}

The historical developments in the time series analysis started initially with stochastic processes. The first real application of autoregressive model to the data has been used by G. U Yule and J. Walker [10].

H. A. Wold developed "Autoregressive Moving Average" (ARMA) model for stationary data, but it was not able to develop a likelihood function of maximum likelihood estimation of the parameters [11].

G. Box and G. Jenkins written a common book 'Time Series Analysis'. This book contains the full modeling procedure for individual series, condition, approximation, diagnostics and prediction. Currently, most important tools like Box-Jenkins models are commonly used for forecasting [12]. M. G Kendall also written an important book on Time Series [13].

ARIMA models are the finest models to predict a time series commonly used. For a stationary time series, the ARIMA models are a linear equation in which the forecasters include lags of dependent variables and/or residuals.

ARIMA models ' unique classes are "random walk", "random trend", "autoregressive" and "exponential models of smoothing". ARIMA "non-seasonal" model is grouped together as ARIMA (p, d, q).

Where;

'p' denotes "the order of autoregressive terms"

'd' represents "the order of differences"

"q' denotes "the order of moving-average terms"

Let $\mathrm{y}$ denote the dth difference of $\mathrm{Y}$, then, the predicting equation can be written as,

if, $\mathrm{d}$ is zero; $\mathrm{yt}=\mathrm{Y}(\mathrm{t})$

if, $\mathrm{d}$ is one; $\mathrm{yt}=\mathrm{Y}(\mathrm{t})-\mathrm{Y}(\mathrm{t}-1)$

(2)

if, $\mathrm{d}$ is two ; $\mathrm{yt}=[\mathrm{Y}(\mathrm{t})-\mathrm{Y}(\mathrm{t}-1)]-[\mathrm{Y}(\mathrm{t}-1)-\mathrm{Y}(\mathrm{t}-2)]$

(3)

$$
=\mathrm{Y}(\mathrm{t})-2 \mathrm{Y}(\mathrm{t}-1)+\mathrm{Y}(\mathrm{t}-2)
$$

The common predicting equation is written as:

$\hat{\mathrm{Y}} \mathrm{t}=\mu+\phi 1 * \mathrm{y}(\mathrm{t}-1)+\ldots+\phi \mathrm{p} * \mathrm{y}(\mathrm{t}-\mathrm{p})-\theta 1 * \mathrm{e}(\mathrm{t}-1)-\ldots-\theta \mathrm{q} *$ $\mathrm{e}(\mathrm{t}-\mathrm{q})$

Where, the "parameters of moving-average" ( $\theta$ 's) are defined. Therefore, the symbols are negative in the equation and follow the bond developed by Box and Jenkins.

\section{RESULT AND FINDINGS}

\subsection{DATA}

The data regarding the total annual Crude oil export of the kingdom was collected from Saudi Arabian Monetary Authority (SAMA). It comprises of yearly basis and was in Saudi Arabian Riyal (SAR) from the years 1968 to 2017. 


\subsection{SUMMARY STATISTICS}

The summary statistics for exports and imports data of the Kingdom are given below in the table 1 .

Table 1: Summary Statistics of Total Annual Crude Oil Export (in million barrels)

\begin{tabular}{|c|c|c|c|c|c|}
\hline Variable & $\begin{array}{c}\text { Observ } \\
\text { ations }\end{array}$ & $\begin{array}{c}\text { Minimu } \\
\mathbf{m}\end{array}$ & Maximum & Mean & $\begin{array}{c}\text { Std. } \\
\text { deviation }\end{array}$ \\
\hline $\begin{array}{c}\text { Total } \\
\text { Annual } \\
\text { Crude Oil } \\
\text { Export }\end{array}$ & 50 & 780.72 & 3375.69 & 2213.83 & 663.326 \\
\hline
\end{tabular}

\subsection{PREDICTION OF TOTAL ANNUAL CRUDE OIL EXPORT}

Table 2: Prediction of Total Annual Crude Oil Export (in million barrels) using different Models

\begin{tabular}{|c|c|c|c|c|c|c|c|c|}
\hline \multirow[b]{2}{*}{ Year } & \multirow[b]{2}{*}{$\begin{array}{c}\text { Actual } \\
\text { Value } \\
\text { of Total } \\
\text { Annual } \\
\text { Crude } \\
\text { Oil } \\
\text { Export } \\
\text { s }\end{array}$} & \multicolumn{7}{|c|}{ Predicted Value of Total Annual Crude Oil Export } \\
\hline & & 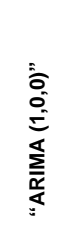 & 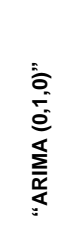 & 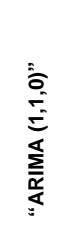 & 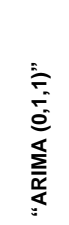 & 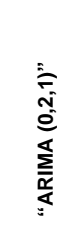 & 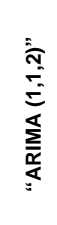 & $\underset{\substack{n \\
z}}{z}$ \\
\hline 2015 & 2614.510 & $\begin{array}{l}2576.9 \\
36\end{array}$ & $\begin{array}{l}2643.1 \\
56\end{array}$ & $\begin{array}{l}2579.3 \\
65\end{array}$ & $\begin{array}{l}2582.8 \\
18\end{array}$ & 2646.377 & $\begin{array}{l}2582 . \\
058\end{array}$ & $\begin{array}{l}2736.2 \\
068\end{array}$ \\
\hline 2016 & 2731.591 & $\begin{array}{l}2580.3 \\
90\end{array}$ & $\begin{array}{l}2646.6 \\
56\end{array}$ & $\begin{array}{l}2615.2 \\
37\end{array}$ & $\begin{array}{l}2620.7 \\
22\end{array}$ & 2650.395 & $\begin{array}{l}2608 . \\
025\end{array}$ & $\begin{array}{l}2630.4 \\
540\end{array}$ \\
\hline 2017 & 2543.440 & $\begin{array}{l}2695.9 \\
43\end{array}$ & $\begin{array}{l}2763.7 \\
37\end{array}$ & $\begin{array}{l}2755.9 \\
17\end{array}$ & $\begin{array}{l}2753.3 \\
23\end{array}$ & 2766.020 & $\begin{array}{l}2753 . \\
270\end{array}$ & $\begin{array}{l}2560.0 \\
545\end{array}$ \\
\hline 2018 & & $\begin{array}{l}2510.2 \\
47\end{array}$ & $\begin{array}{l}2543.4 \\
40\end{array}$ & $\begin{array}{l}2504.3 \\
49\end{array}$ & $\begin{array}{l}2502.3 \\
00\end{array}$ & 2573.326 & $\begin{array}{l}2511 . \\
867\end{array}$ & $\begin{array}{l}2547.1 \\
121\end{array}$ \\
\hline 2019 & & $\begin{array}{l}2477.4 \\
88\end{array}$ & $\begin{array}{l}2543.4 \\
40\end{array}$ & $\begin{array}{l}2496.2 \\
27\end{array}$ & $\begin{array}{l}2502.3 \\
00\end{array}$ & 2603.212 & $\begin{array}{l}2497 . \\
685\end{array}$ & $\begin{array}{l}2718.2 \\
686\end{array}$ \\
\hline 2020 & & $\begin{array}{l}2445.1 \\
56\end{array}$ & $\begin{array}{l}2543.4 \\
40\end{array}$ & $\begin{array}{l}2494.5 \\
39\end{array}$ & $\begin{array}{l}2502.3 \\
00\end{array}$ & 2633.099 & $\begin{array}{l}2491 . \\
707\end{array}$ & $\begin{array}{l}2764.1 \\
658\end{array}$ \\
\hline
\end{tabular}

ANN and ARIMA models are used to create the predictions for future values of the time series by using the Statistical Software.

From the above Table 2, it is observed that the best prediction is provided by ANN and then ARIMA $(0,2,1)$. Thus, we concluded that ANN model predict the export of crude oil more efficiently than other ARIMA models.

\subsection{MODELS FOR TOTAL ANNUAL CRUDE OIL EXPORT}

\subsubsection{Graph of Total Annual Crude Oil Export using Neural Network}

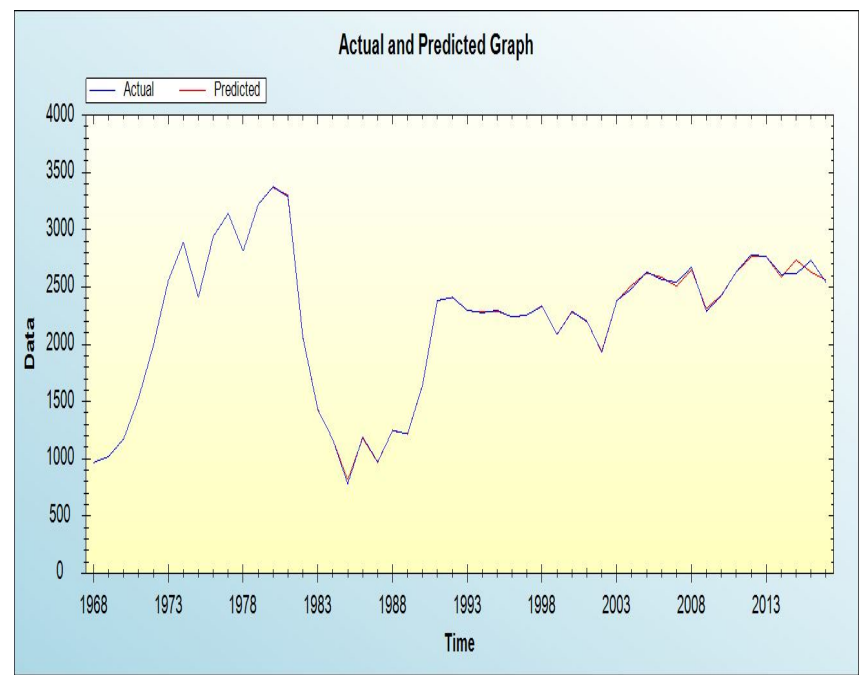

Figure 2: Graph of Total Annual Crude Oil Export using ANN

\subsubsection{Graph of Total Annual Crude Oil Export using ARIMA (0, 2, 1)}

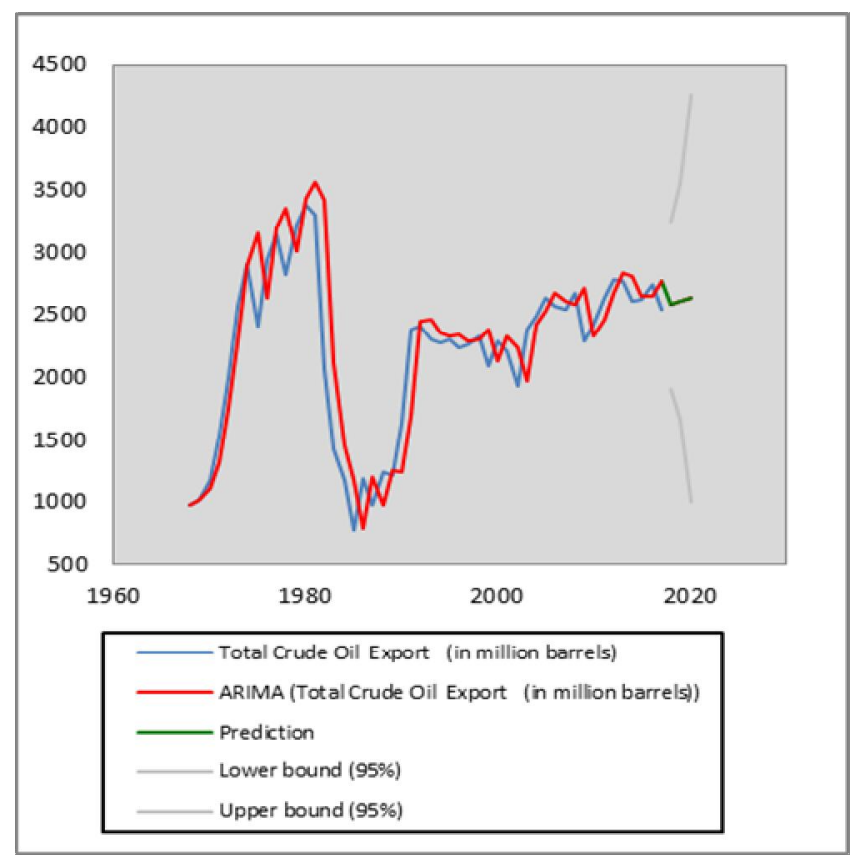

Figure 3: Graph of Total Annual Crude Oil Export using $\operatorname{ARIMA}(0,2,1)$

It is evident from the above figure 2 and 3 ; the total annual crude oil export of the Kingdom is gradually increasing and decreasing over the time till the year 1986 and after that it was continually increasing up to the year 1992. Also, it is evident from the above figures that exports decreasing after 1992 up to 2003. After that, it was gradually increasing. 


\subsubsection{Plot of ACF and PACF of Total Annual Crude Oil Export}

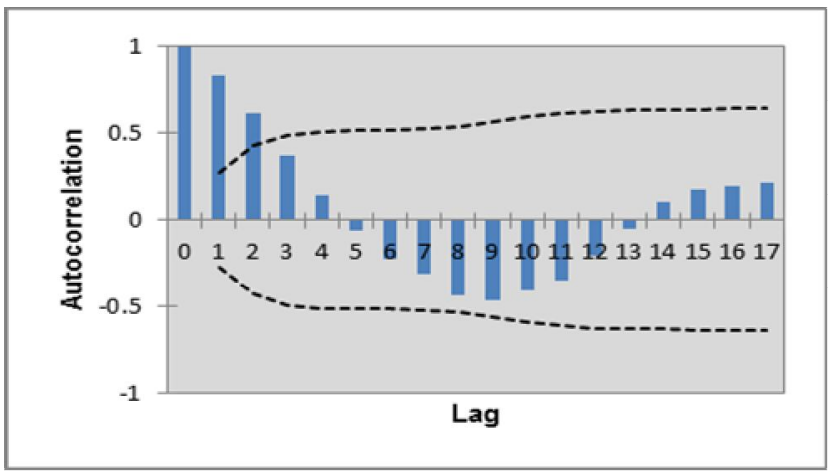

Figure 4: Plot of ACF of Total Annual Crude Oil Export

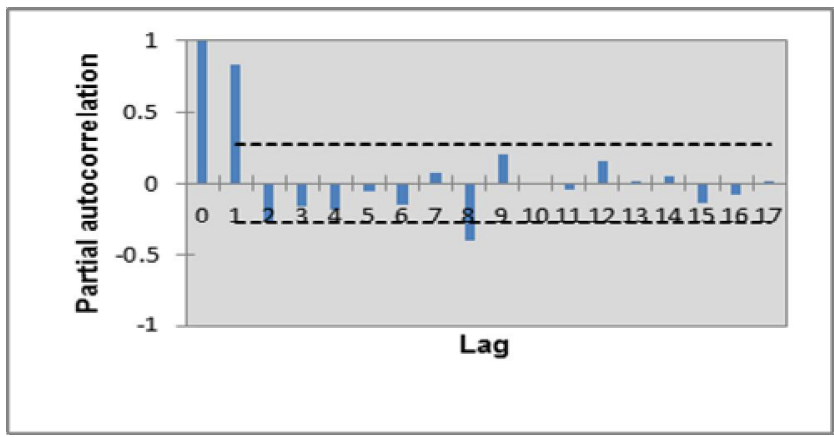

Figure 5: Plot of PACF of Total Annual Crude Oil Export

From the figure 4 and figure 5 ; it is observed that the autocorrelation and partial autocorrelation are positive, negative and positive, which indicates that there are possible shifts in both the mean and the variability over time for this series. It means the arithmetic mean may be edging upwards and downwards, and the variability may be increasing and decreasing.

\subsection{RESIDUAL ANALYTIC FOR ANN MODEL}

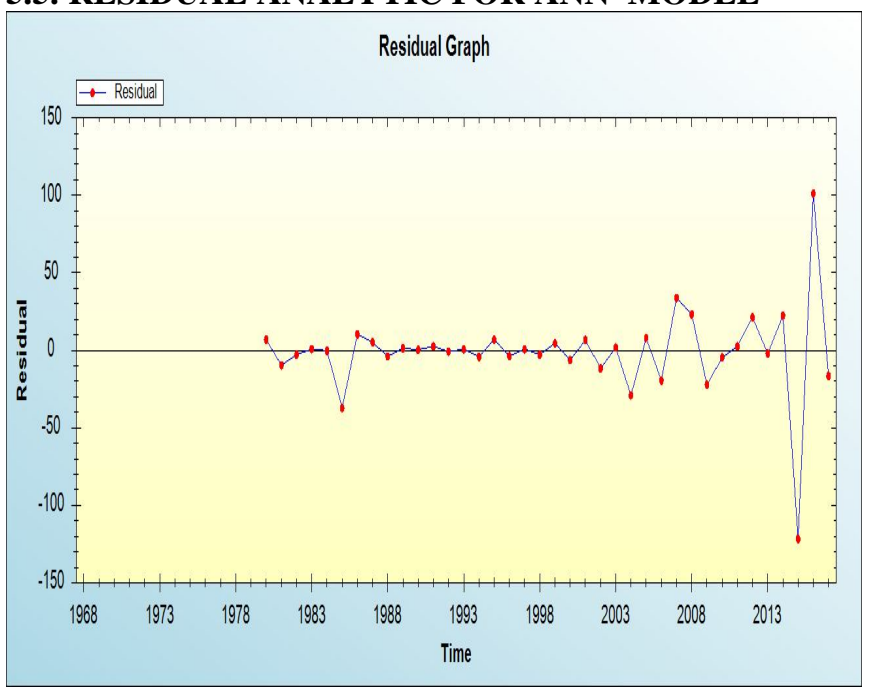

Figure 6: Residual Graph of Total Annual Crude Oil Export using ANN model

\subsection{RESIDUAL ANALYTIC FOR ARIMA (0, 2, 1) MODEL}

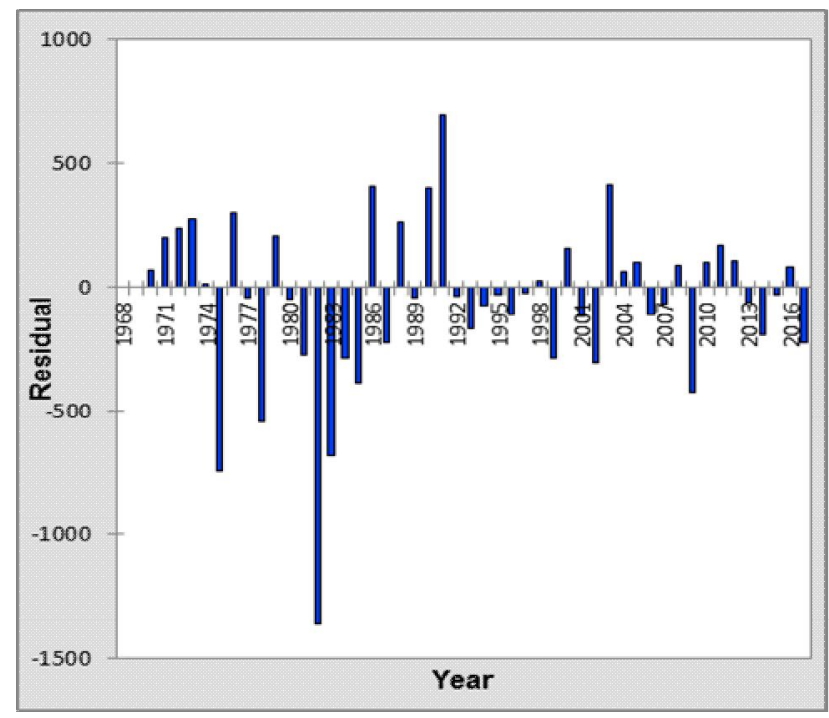

Figure 7: Residual Graph of Total Annual Crude Oil Export using ARIMA $(0,2,1)$

It is evident from the Figure 6 and 7; the residuals of the total annual crude oil export of the models shows analytic plots that are useful in making decisions.

From the aforementioned figures, we can say that the time series graph of the residuals model enables us to search for patterns in the residuals.

It is obvious from the time series graph appeared in the Figure 5 and 6 that the arrangement of residuals is a stationary series.

\section{CONCLUSION AND SUGGESTION}

The basic aim of the study is to predict the total annual crude oil exports of the Kingdom of Saudi Arabia.

ANN model is one of the finest methods with any pattern of change to predict the amount of any time series data and is appropriate for at least fifty observations.

From the assessment, we conclude that ANN model is the best model to forecast for the Kingdom of Saudi Arabia's annual export of crude oil.

The forecasted value of total annual crude oil export of the Kingdom will be 2764.1658 (in million barrels) in the year 2020 by using ANN, which will be fluctuating as compared to 2015.

The current research, after evaluating the outcomes, indicates that the Government Agency should concentrate on enhancing the following fields-

Crude Oil export nations and import nations around the world should have a healthy connection.

Training sessions and workshops should take place for Crude oil export department staff to be aware of the current status. 


\section{REFERENCES}

[1] J. Uddin. Time series behaviour of imports and exports of Bangladesh: evidence from cointegration analysis and error correction model, International Journal of Economic and Finance, 2009, 1:2. DOI:10.5539/ijef.v1n2p156

[2] Mohammad, E. B. Mohammad and M. R. B. Sayyed. Parameters estimates of autoregressive moving average and autoregressive integrated moving average models and compare their ability for inflow forecasting, Journal of Mathematics and Statistics 8(3), 2012, pp. 330-338.

DOI : $10.3844 /$ jmssp.2012.330.338

[3] J. T. Olajide, O. A. Ayansola, M. T. Odusina and I. F. Oyenuga. Forecasting the Inflation Rate in Nigeria: Box Jenkins Approach, IOSR Journal of Mathematics (IOSR-JM) Volume 3, Issue 5, 2012, pp. 15-19. DOI: 10.9790/5728-0351519

[4] Tektas Mehmat. Weather Forecasting Using ANFIS and ARIMA MODELS, A Case Study for Istanbul Environmental Research, Engineering and Management, No. 1(51), 2010, pp. 5-10.

DOI: $10.5755 / \mathrm{j} 01 . e r e m .51 .1 .58$

[5] G.M. Ljung, and G. Box. On a Measure of Lack of Fit in Time Series Models, Biometrika, 65, 1978, pp.297-303.

[6] Tularam G. A. and Saeed T. Oil-Price Forecasting Based on Various Univariate Time-Series Models, American Journal of Operations Research, 2016, 6, 226-235. http://dx.doi.org/10.4236/ajor.2016.63023
[7] Biljana Petrevska. Predicting tourism demand by A.R.I.M.A. models, Economic Research, 201730:1, 939-950, https://doi.org/10.1080/1331677X.2017.1314822

[8] Anthony Nyangarika, Alexey Mikhaylov, Ulf Henning Richter. Oil Price Factors: Forecasting on the Base of Modified Auto-regressive Integrated Moving Average Model, International Journal of Energy Economics and Policy, 2019, 9(1), 149-159. https://doi.org/10.32479/ijeep.6812

[9] Wiri, Leneenadogo and Tuaneh, Godwin Lebari. Modeling the Nigeria Crude Oil Prices Using ARIMA, re-intervention and Post-intervention Model, Asian Journal of Probability and Statistics, 2019, 3(1): $1-12$. 10.9734/AJPAS/2019/v3i130083

[10] G. U. Yule. On a Method of Investigating Periodicities in Disturbed Series, with Special reference to Wolfer's Sunspot Numbers, Philosophical Transactions, (A) 226, 1927, pp. 267-98.

[11] H. A. Wold. Study in the Analysis of Stationary Time Series, Stockholm: Almquist and iksell, 1938.

[12] G. Box, G. Jenkins. Time-Series Analysis: Forecasting and Control, San Francisco, CA: Holden-Day Press, 1970.

[13] M. G Kendall. Time series, Griffin and Co ltd, London, 1995.

[14] https://atlas.media.mit.edu/en/profile/country/sau/

[15] http://www.sama.gov.sa/en 